\title{
Mixed Germ Cell Tumor
}

National Cancer Institute

\section{Source}

National Cancer Institute. Mixed Germ Cell Tumor. NCI Thesaurus. Code C4290.

A malignant germ cell tumor characterized by the presence of at least two different germ cell tumor components. The different germ cell tumor components include choriocarcinoma, embryonal carcinoma, yolk sac tumor, teratoma, and seminoma. It occurs in the ovary, testis, and extragonadal sites including central nervous system and mediastinum. 